\title{
Peningkatan Kemampuan Berpikir Kreatif Matematik melalui Penerapan Pembelajaran Kooperatif Tipe TAI dan Soal Open Ended
}

\author{
Akhirman', Nilna Ma'Rifah' \\ ${ }^{1}$ Mahasiswa S2 Pendidikan Matematika Universitas Bengkulu \\ ${ }^{2}$ Guru Matematika Kabupaten Rejang Lebong \\ 1akhirmanman@yahoo.com, ${ }^{1}$ nilnamarifah@gmail.com
}

\begin{abstract}
Abstrak. Tujuan penelitian adalah mengetahui cara menerapkan Pembelajaran Kooperatif tipe Team Assisted Individualization (TAI) menggunakan Soal Open Ended, untuk meningkatkan kemampuan berpikir kreatif mahasiswa IAIN Curup. Jenis penelitian yang dilaksanakan adalah penelitian tindakan kelas (PTK). dengan teknik pengumpulan data menggunakan tes kemampuan berpikir kreatif dan berpikir kritis. Subjek dalam penelitian ini adalah mahasiswa Tadris Matematika Semester III IAIN Curup. Hasil penelitian menunjukan Pembelajaran Kooperatif tipe Team Assisted Individualization (TAI) menggunakan Soal Open Ended, dapat meningkatkan kemampuan berpikir kreatif dengan cara membentuk kelompok baru dengan berdasarkan hasil tes kemampuan Berpikir Kreatif bertanya kepada salah satu anggota kelompok tentang jawaban dari soal open ended yang diperoleh pada saat mengerjakan Lembar Tugas di Student Creative dan belajar kelompok, memberikan pengurangan nilai jika mahasiswa menyalin lembar jawaban dan tidak mengerjakan soal sesuai tipe, menentukan tipe soal yang dikerjakan oleh mahasiswa dan mahasiswa wajib memberikan tanda tangan seteleh mengecek jawaban mahasiswa. Peningkatan tes kemampuan berpikir kreatif mahasiswa dari Siklus I ke Siklus II sebesar 16,92.
\end{abstract}

\section{Kata kunci: Berpikir Kreatif, Team Assisted Individualization (TAI), Soal open ended}

\section{Pendahuluan}

Matematika dalam aplikasinya memiliki peranan penting dalam kehidupan sehari-hari. Peranan dalam kehidupan bersekolah ataupun dalam kehidupan seharihari. Kondisi ini membuat umumnya, pembelajaran matematika memiliki jam pelajaran yang lebih banyak dalam pelaksanaannya. Hal ini dilakukan karena mata pelajaran matematika bukan hanya matematika itu sendiri, tetapi matematika merupakan suatu pengetahuan yang mempunyai karakteristik berpikir logis, kritis, sistematis, tekun, kreatif dan banyak nilai-nilai luhur matematika bermanfaat untuk berbagai jenis dan program sekolah.

Peranan penting matematika ini didukung dengan pembaharuan dalam cara mengajar matematika. Perubahan dan perkembangan zaman yang semakin pesat membuat pembelajaran matematika juga harus mengikuti alur zaman agar dapat diterima pada semua kalangan. Kemampuan akan diperoleh jika tujuan 
pembelajaran matematika tercapai namun, pelaksanaannya pembelajaran matematika kurang diminati oleh mahasiswa sehingga, mahasiswa merasa sulit untuk memahaminya. Pandangan tersebut mengakibatkan kemampuan belajar matematika menurun.

Berdasarkan informasi yang diperoleh dalam observasi dengan mahasiswa tadris matematika IAIN Curup kemampuan matematis terutama kemampuan berpikir kreatif masih dalam kategori kurang. Berdasarkan permasalahan yang telah diungkapkan di atas, menunjukan bahwa diperlukan suatu perubahan cara mengajar yang dilakukan oleh dosen. Perubahan dapat dilakukan dengan menerapkan model pembelajaran yang berbeda dari biasanya. Salah satu model pembelajaran yang dapat diterapkan untuk mengatasi masalah tersebut ialah model pembelajaran kooperatif. Pembelajaran Kooperatif terdiri dari kata pembelajaran dan kooperatif. Kooperatif dalam bahasa inggris disebut cooperatif yang artinya mengerjakan sesuatu secara bersama-sama dengan saling membantu satu sama lainnya sebagai satu kelompok atau satu tim (Isjoni, 2013: 15). Model pembelajaran kooperatif ini memiliki banyak tipe. Salah satu tipe yang dapat diterapkan dalam pembelajaran matematika yaitu tipe Team Assisted Individualization (TAI).

Model pembelajaran Team Assisted Individualization (TAI) merupakan pembelajaran kooperatif yang dasar pemikirannya adalah untuk mengadaptasi pengajaran terhadap perbedaan individual berkaitan dengan kemampuan mahasiswa maupun pencapaian prestasi mahasiswa (Slavin,2005:187).Dalam pembelajaran ini mahasiswa diberikan tugas untuk dikerjakan secara individu dan teman dalam satu kelompok melakukan pengecekan jawaban tugas. Hal ini dapat mengatasi masalah mahasiswa yang terbiasa mengandalkan salah seorang anggota kelompok dalam penyelesaian tugas.

Tugas pada model pembelajaran Team Assisted Individualization (TAI) dapat menyetarakan pemahaman mahasiswa terhadap materi karena dalam mengerjakan persoalan dalam tugas harus secara bertahap. Mahasiswa akan termotivasi untuk mempelajari materi dengan mengerjakan tugas secara cepat dan akurat. Hal ini sejalan dengan pendapat Shoimin (2014:202) bahwa kelebihan pembelajaran TAI adalah mahasiswa diajarkan bagaimana bekerja sama dalam kelompok dan melibatkan mahasiswa untuk aktif belajar. Tugas menggunakan soal open ended yang berisi persoalan terbuka dimana mahasiswa diminta mengembangkan metode dancara yang berbeda dalam menjawab permasalahan yang diberikan dan bukan berorientasi pada jawaban akhir. Hal ini sejalan dengan pendapat Wijaya (2012:61) bahwa bahwa salah satu manfaat open ended adalah mahasiswa dapat bebas memberikan berbagai tanggapan yang berbeda terhadap masalah yang dikerjakan. Shoimin (2014:110) mendefinisikan problem open ended adalah problem yang diformulasikan memiliki banyak jawaban yang benar serta mengarahkan mahasiswa untuk menggunakan keragaman cara penyelesaian sehingga sampai pada suatu jawaban yang diinginkan. Pemberian soal open ended mengatasi persoalan pembelajaran yang hanya menggunakan soal latihan yang terdapat pada buku paket sehingga dapat meningkatkan aktivitas belajar. 
Kegiatan matematika dan kegiatan mahasiswa disebut terbuka menurut Suherman dkk (2003: 124) jika memenuhi ketiga aspek yaitu

1. Kegiatan mahasiswa harus tebuka.

2. Kegiatan matematika adalah ragam berpikir.

3. Kegiatan mahasiswa dan kegiatan matematika merupakan satu kesatuan.

Sehingga, dalam kegiatan pembelajaran terdapat kesempatan mahasiswa untuk melakukan kegiatan secara bebas. Kegiatan yang dilakukan didalamnya akan melatih keterampilan mahasiswa dalam menggeneralisasi masalah. Adapun dosen tidak perlu mengarahkan mahasiswa memecahkan masalah dengan cara yang ditentukan agar tidak menghambat cara berpikir mahasiswa.

Penggunaan soal open ended pada materi geometri analitik seperti Parabola, parabola dan lingkaran dapat meningkatkan penguasaan materi mahasiswa. Peningkatan terjadi karena masalah dalam open ended menggunakan masalah terbuka sehingga, mahasiswa dapat mencari cara yang berbeda dalam menemukan solusi yang tepat pada soal bangun ruang sisi datar. Penggunaan soal open ended juga akan menumbuhkan ide, kreatifitas serta lebih mementingkan proses dari pada hasil sehingga mahasiswa akan aktif dalam proses pembelajaran sehingga kemamapuan berpikir kreatif mahasiswa dapat meningkat.

Kemampuan berpikir kreatif merupakan salah satu kemampuan siswa yang harus dikembangkan dalam proses pembelajaran. Sesuai dengan Pasal 2 Undangundang Nomor 20 Tahun 2003 tentang Sistem Pendidikan Nasional dalam pasal 3 bahwa pendidikan nasional berfungsi mengembangkan kemampuan dan membentuk watak serta peradaban bangsa yang bermartabat dalam rangka mencerdaskan kehidupan bangsa, bertujuan untuk mengembangkan potensi peserta didik agar menjadi manusia yang beriman dan bertakwa kepada Tuhan Yang Maha Esa, berakhlak mulia, sehat, berilmu, cakap, kreatif, mandiri, dan menjadi warga negara yang demokratis serta bertanggung jawab (Depdiknas,

2006:105). Melalui pembelajaran matematika, siswa diharapkan memiliki kemampuan berpikir kreatif sesuai dengan tujuan pendidikan di Indonesia.

Adapun kemampuan berpikir kreatif matematis yang dimaksud adalah kemampuan mengemukakan ide-ide dalam menyelesaikan soal-soal matematika. Menurut Huda (2011), berpikir kreatif adalah suatu pemikiran yang berusaha menciptakan gagasan yang baru. Berpikir kreatif dapat juga diartikan sebagai suatu kegiatan mental yang digunakan seorang untuk membangun ide atau pemikiran yang baru. Sedangkan Pehkonen (1997) memandang bahwa berpikir kreatif sebagai suatu kombinasi dari berpikir logis dan berpikir divergen yang didasarkan pada intuisi tetapi masih dalam kesadaran. Berpikir divergen sendiri adalah memberikan bermacam-macam kemungkinan jawaban dari pertanyaan yang sama. Munandar (2019: 192) mendefinisikan kemampuan berpikir kreatif matematis adalah kemampuan dalam matematika yang meliputi empat kriteria, antara lain kelancaran, kelenturan (fleksibilitas), keaslian (orisinalitas) dan kerincian (elaborasi). Kelancaran menjawab adalah kemampuan peserta didik dalam mencetuskan penyelesaian masalah, atau pertanyaan matematika secara tepat. Kelenturan 
menjawab adalah kemampuan peserta didik dalam menghasilkan gagasan, jawaban, atau pertanyaan yang bervariasi namun harus tetap mengacu pada masalah yang diberikan. Keaslian adalah kemampuan menjawab masalah matematika menggunakan bahasa, cara atau idenya sendiri sehingga ide tersebut tidak pernah terpikirkan oleh orang lain. Elaborasi adalah kemampuan mengembangkan jawaban masalah, gagasan sendiri ataupun gagasan orang lain. Berdasarkan penjelesan diatas, kemampuan berpikir kreatis sangat penting dalam menunjang pembelajara. siswa memerlukan dorongan untuk mewujudkan potensi keratifnya, siswa harus diberi kesempatan untuk terlibat aktif dalam proses pemecahan masalah secara kreatif. oleh karena itu dosen harus dapat memfasilitasi suatu pembelajaran yang dapat membantu siswa untuk berpikir kreatif.

Berdasarkan uraian di muka maka peneliti termotivasi untuk melaksanakan penelitian yang berjudul " Penerapan Pembelajaran Kooperatif tipe Team Assisted Individualization (TAI) menggunakan Soal Open Ended untuk Meningkatkan Kemampuan Berpikir Kreatif Mahasiswa IAIN Curup".

\section{Metode}

Jenis penelitian yang dilakukan pada penelitian ini adalah Penelitian Tindakan Kelas (PTK) atau Classroom Action Research (CAR). Menurut Sanjaya (2013:149) PTK (penelitian tindak kelas) adalah proses pengkajian masalah pembelajaran di dalam kelas melalui refleksi diri dan upaya untuk memecahkannya dengan cara melakukan berbagai tindakan yang terancana dalam situasi nyata serta menganalisis setiap pengaruh dari tindakan tersebut.. Subjek dari penelitian tindakan kelas ini adalah mahasiswa Tadris Matematika IAIN Curup tahun ajaran 2018/2019 dengan jumlah mahasiswa 17. Peneliti memilih mahasiswa Semester III sebagai subjek penelitian karena berdasarkan penempatan PIPM dan atas saran dosen.

\section{Hasil Dan Pembahasan}

Berdasarkan pembelajaran yang dilakukan secara menyelurug pada Siklus I dan Siklus II pada mahasiswa Tadris Matematika Semester III dengan penerapan pembelajaran kooperatif tipe Team Assisted Individualization (TAI) menggunakan soal Open Ended, bahwa terjadi peningkatan kemampuan berpikir Kreatif sesuai dengan indilator. Kategori berpikir kreatif mahasiswa diperoleh dari hasil analisis jawaban mahasiswa pada kedua siklus pad tes open ended dan dilihat darinkemmapuan mahasiswa dalam memenuhi aspek-aspek berpikir Kreatif. Dari data yang diperoleh kemampuan berpikir kreatif mahasiswa diinterpretasikan ke dalan dua soal pada Siklus I dan 4 soal pada Siklus II. Adapun rekapitulasi presentase kemampuan berpikir kreatif mahasiswa Tadris Matematika Semester III pada masing-masing kategori dilihat pada Tabel 1.

Tabel 1 Rekapitulasi jumlah mahasiswa tiap kategori kemmpuan berpikir Kreatif 
Jurnal Pendidikan Matematika Raflesia

Vol. 04 No. 01, Juni 2019

https://ejournal.unib.ac.id/index.php/jpmr

P-ISSN : 2548-4435(Media Printed) E-ISSN : 2615-8752 (Media Online)

\begin{tabular}{|c|c|c|c|}
\hline Ketentuan & Kategori & $\begin{array}{c}\text { Jumlah Mahasiswa } \\
\text { Siklus I }\end{array}$ & $\begin{array}{c}\text { Jumlah } \\
\text { Mahasiswa } \\
\text { Siklus II }\end{array}$ \\
\hline $90 \leq x \leq 100$ & Sangat baik & 1 & 4 \\
\hline $80 \leq x<90$ & Baik & 0 & 7 \\
\hline $70 \leq x<80$ & Cukup & 4 & 6 \\
\hline $60 \leq x<70$ & Kurang & 12 & 0 \\
\hline$x<60$ & Sangat kurang & 0 & 0 \\
\hline
\end{tabular}

Secara visual perbandingan mahasiswa yang menempati kelima kategori tersebut dapat dilihat pada Gambar 1 dan Gambar 2.

\section{Siklus I}

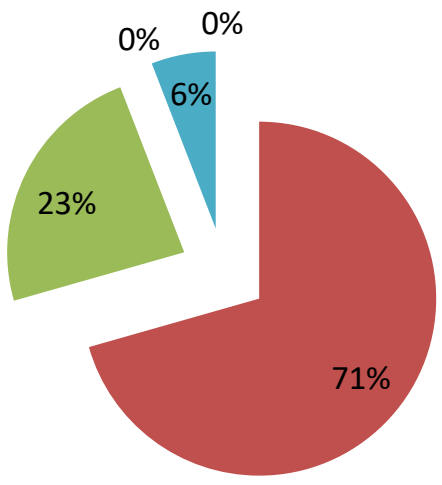

Sangat Kurang

Kurang

Cukup

Baik

- Sangat Baik

Gambar 1 Kemampuan Mahasiswa Siklus I

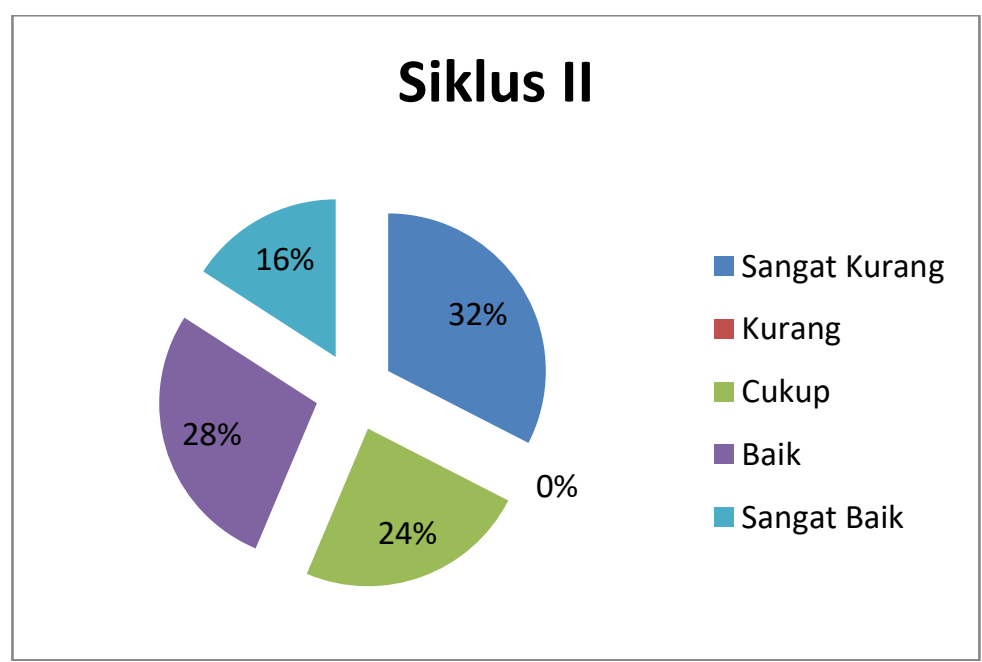

Gambar 2 Kemampuan Mahasiswa Siklus II 
Berdasarkan Gambar 1 dan Gambar 2, kemampuan berpikir kreatif mahasiswa pada mata kuliah Geometri analitik pada Siklus I berada pada kategori Kurang. Siklus II kemampuan berpikir Kreatif meningkat menjadi Baik kemudian disusul oleh kemampuan berpikirkreatif dengan kategori kurang dan cukup. RataRata yang diperoleh siswa pada Siklus I adalah sebesar 68,34. Nilai maksimal yang diperoleh siswa adalah 94,27 dan nilai minimal siswa adalah 60,2. Kondisi ini mengalami peningkatan di Siklus II dimana, Nilai rata-rata menjadi 83,3. Perolehan nilai tersebut menunjukan bahwa tidak terdapat mahasiswa dengan kemampuan berpikir kereatif nol.

Data ini didapatkan dari jawaban mahasiswa yang telah dianalisis sesuai dengan rubrik jawaban dan pedoman penskoran yang mencakup aspek fluency, flexibility, originality dan elaboration. Hasil Perhitungan ketercapaian aspek berpikir kreatif tersebut tercantum pada Tabel 2.

Tabel 2. Ketercapaian Aspek Berpikir Kreatif

\begin{tabular}{|l|c|c|c|c|}
\hline \multicolumn{1}{|c|}{$\begin{array}{c}\text { Aspek-Aspek } \\
\text { Kemampuan } \\
\text { Berpikir Kreatif }\end{array}$} & $\begin{array}{c}\text { Rata-rata } \\
\text { Siklus I }\end{array}$ & Kategori & $\begin{array}{c}\text { Rata-Rata } \\
\text { Siklus II }\end{array}$ & Kategori \\
\hline $\begin{array}{l}\text { Kelancaran } \\
\text { (Fluency) }\end{array}$ & 67,82 & Cukup & 80,95 & Baik \\
\hline $\begin{array}{l}\text { Keluwesan } \\
\text { (Flexibility) }\end{array}$ & 63,09 & Cukup & 75,65 & Baik \\
\hline $\begin{array}{l}\text { Keaslian } \\
\text { (Originality) }\end{array}$ & 15,43 & Kurang & 45,37 & Kurang \\
\hline $\begin{array}{l}\text { Memerinci } \\
\text { (Elaboration) }\end{array}$ & Baik \\
\hline
\end{tabular}

Berdasarkan Tabel pencapian rata-rata aspek Fluency yang diperoleh awalnya dalam kategori Cukup dan meningkat pada Siklus II menjadi 80,95 dengan kategori baik. Keterampilan berpikir lancar didefinisikan sebagai keterampilan dalam menghasilkan banyak gagasan atau jawaban yang relevan serta arus pemikiran yang lancar (Munandar,2009:192). Soal pada aspek kelancaran ada pada setiap soal pada Siklus I dan II. Soal pada indikator ini menidentifikasi kelancaran yang diwujudkan dengan menuliskan persamaan pada irisan kerucut dari konsep matematika.

Aspek Keluwesan (Flexibility) pada Siklus I memperoleh hasil tes sebesar 72,10 dan meningkat menjadi 85,67 adapun semua berada pada kategori Baik. Keluwesan didefinisikan sebagai keterampilan dalam menghasilkan gagasan atau pertanyaan yang bervariaso, mampu mengubah cara pendekatan serta memiliki arah permikiran yang berbeda (Munandar, 2009:192). Soal yang menjaring keluwesan terdapat pada setiap soal dimana mahasiswa diminta menyusun masalah berdasarkan situasi yang diberikan pada materi irisan kerucut.

Aspek keaslian (Originality) yang diperoleh dari hasil tes Open ended pada Siklus I sebesar 63,09 berada pada kategori kurang dan mengalami peningkatan di Siklus II sebesar 75,65 pada kategori baik. Keaslian didefinisikan sebagai keterampilan dalam memberikan jawaban yang tidak lazim, yang lain dari yang 
lain, yang jarang di berikan kebanyakan orang (Munandar, 2009:192). Peningkatan presentase rata-rata nilai mahasiswa dilatarbelakangi oleh pemahaman mahasiswa yang sudah baik terkait konsep irisan kerucut dan sudah terbiasa menggunakan soal Open Ended.

Persentase Aspek Memerinci (Elaboration) pada Siklus I adalah 15, $43 \%$ dan meningkat menjadi $45,37 \%$ keduanya masih dalam kategori kurang. Keterincian didefinisikan sebagai keterampilan dalam mengembangkan, menambahkan, memoerkayan suatu gagasan atau merinci detail-detail, serta memperluas suatu gagasan (Munandar, 2009:192). Walaupun, aspek ini meningkat namun masih dalam kategori kurang. Hal ini dikarenakan mahasiswa masih kebingungan untuk menjawab soal. meskipun sebenarnya memahami apa yang ditanyakan dalam soal tersebut. Kondisi ini menunjukan bahwa Pembelajaran Kooperatif tipe Team Assisted Individualization (TAI) menggunakan Soal Open Ended agar dapat meningkatkan Kemampuan Berpikir Kreatif.

\section{Simpulan}

Berdasarkan hasil penelitian yang telah dilakukan di Tadris Matematika IAIN Curup Semester III diperoleh penerapan Pembelajaran Kooperatif tipe Team Assisted Individualization (TAI) menggunakan Soal Open Ended agar dapat meningkatkan Kemampuan Berpikir Kreatif dengan cara :

a. Pada tahap Teams, membentuk kelompok baru dengan berdasarkan hasil tes kemampuan Berpikir Kreatif.

b. Dosen model sering bertanya kepada salah satu anggota kelompok tentang jawaban dari soal open ended yang diperoleh pada saat mengerjakan Lembar Tugas di Student Creative dan belajar kelompok.

c. Dosen model memberikan pengurangan nilai jika mahasiswa menyalin lembar jawaban dan tidak mengerjakan soal sesuai tipe.

d. Dosen model menginformasikan perwakilan kelompok pada tahap Teaching group ditentukan dengan acak sehingga setiap anggota mempersiapkan diri untuk belajar menjelaskan dan menguasai materi.

e. Dosen model mengambil lembar tes fakta mahasiwa jika tidak mengerjakan tes secara individua.

Kegiatan tersebut terbukti dapat meningkatkan kemampuan berpikir kreatif dari Siklus I sampai Siklus II. Nilai akhir Siklus I menunjukan rata-rata mahasiswa 67,78, kemudian pada Siklus II nilai tes meningkat dengan rata-rata 84,706.

\section{DAFTAR PUSTAKA}

Depdiknas. (2006). Kurikulum Tingkat Satuan Pendidikan. Jakarta : Depdiknas Huda, C. (2011). Meningkatkan Kemampuan Berpikir Kreatif Siswa dalam Memecahkan

Masalah Matematika dengan Model Pembelajaran Treffinger pada Materi Pokok Keliling dan Luas Persegi panjang. (Online). (http://digilib.sunanampel.ac.id/gdl.php?mod=browse\&op=read\&id=jiptiain-- 
chotmilhud-9908., diakses 21 September 2018)

Isjoni, 2013. Cooperatif Learning: Mengembangkan Kemampuan Belajar Kelompok. Bandung: Alfabeta

Munandar, Utami. (2009). Pengembangan Kreatifitas Anak Berbakat. Jakarta : Rineka Cipta

Pehkonen, E. (1997). The State of Art in Mathematical Creativity. http://www.fiz.karlsruhe.de/fiz/publications/zdm. ZDM, 29 (3), 43.

Sanjaya, Wina. (2013). Penelitian Pendidikan : Jenis, Metode dan Prosedur. Jakarta : Kakilangit Kencana.

Shoimin, Aris. (2014). 68 Model Pembelajaran Inovatif dalam Kurikulum 2013. Yogyakarta : AR-RUZZ MEDIA.

Slavin, R. (2005). Cooperative Learning Teori, Riset dan Praktik. Terjemahan Oleh Narulita Yusron. Tanpa tahun. Bandung: Nusa Media.

Suherman dkk. (2003). Strategi Pembelejaran Matematika Kontemporer. FKIP Matematika UPI.

Wijaya, Ariyadi. (2012). Pendekatan Matematika Realistik: Suatu Alternatif Pendekatan Pembelajaran Matematika. Yogyakarta : Graha Ilmu. 